\title{
Production of glucose-rich enzymatic hydrolysates from cellulosic pulps
}

\author{
Kamila Buzała • Piotr Przybysz • \\ Justyna Rosicka-Kaczmarek • Halina Kalinowska
}

Received: 26 June 2014/ Accepted: 8 December 2014/Published online: 18 December 2014

(C) The Author(s) 2014. This article is published with open access at Springerlink.com

\begin{abstract}
The digestibility of cellulosic pulps derived by the sulfate process was assessed using commercial multienzyme preparations. Poplar wood pulps of relatively low lignin contents (Kappa numbers of 15.4-24.2), birch, beech and pine wood pulps (Kappa numbers of 25.8-31.4), and wheat straw pulp (Kappa number of 29.5) were efficiently hydrolyzed by a commercial preparation NS-22086 from Novozymes, containing cellulases and xylanases. At around $1.3 \%(\mathrm{w} / \mathrm{w})$ substrate concentration, yields of glucose from the poplar pulps were around $80 \%$ on a dry weight (d.w.) basis while for the other four pulps they varied between approximately $70 \%$ (for pine pulp) and $78 \%$ d.w. (for beech and wheat straw pulps). At around $7.4 \%(\mathrm{w} / \mathrm{w})$ poplar pulp (Kappa number of 24.2) concentration, glucose yield was around $61 \%$ d.w. The NS-22086 preparation almost completely
\end{abstract}

K. Buzała $(\bowtie) \cdot$ P. Przybysz

Institute of Papermaking and Printing Technology,

Lodz University of Technology, Wolczanska Str. 223, 90-924 Lodz, Poland

e-mail: buzala.kamila@wp.pl

K. Buzała $\cdot$ H. Kalinowska

Institute of Technical Biochemistry, Lodz University of Technology, Stefanowskiego Str. 4/10, 90-924 Lodz, Poland

\section{J. Rosicka-Kaczmarek}

Institute of Chemical Food Technology, Lodz University of Technology, Stefanowskiego Str. 4/10, 90-924 Lodz, Poland saccharified fines from a paper mill (around $74 \%$ glucose yields on a dry weight basis) while digestion of poplar chips (particle size of 1.6-2.0 mm) and wheat straw chaff (particle size up to $6 \mathrm{~mm}$ ) yielded around 5.3 and $14 \%$ d.w. glucose, respectively (total reducing sugars yields of around 16 and $23 \%$ d.w., respectively). These results show that plant biomass may be efficiently converted to glucose-rich hydrolysates by a two-step processing, consisting of kraft pulping followed by treatment with endo- and exo-type cellulases and hemicellulases. Glucose-rich hydrolysates may be also obtained by enzymatic digestion of fines from paper mills.

Keywords Cellulosic pulps · Wood - Wheat straw · Kraft pulping $\cdot$ Enzymatic hydrolysis

\section{Introduction}

Lignocellulosic biomass has been considered as a renewable, vast, inexpensive and underutilized resource of sugar feedstocks for production of biofuels and valuable chemicals. The rich source of lignocelluloses is wood of various botanical origins and byproducts from its processing. The bioconversion of wood and other lignocellulosic materials into biofuels and other biodegradable chemicals is eco-friendly and enables to avoid competition between their manufacturing and food production. However, cellulose and 
hemicellulose fibers constituting the structural framework of plant cell walls are protected from the attack of depolymerizing enzymes by a strongly cross-linked lignin coating (Santi et al. 2013). To reduce the recalcitrance of lignocellulosic biomass to enzymatic hydrolysis, a number of biomass disintegration and pretreatment methods have been developed (Galbe and Zacchi 2007; Chaturvedi and Verma 2013).

In papermaking, kraft pulping (also called the sulfate process) is the most popular method for converting wood into a pulp consisting of virtually pure cellulose (Chakar and Ragauskas 2004). Wood pulps differ in the lignin and hemicelluloses contents and their purity is often described by the Kappa number, which is approximately proportional to the lignin level, and varies between 1 and 100. For bleachable pulps it ranges between 25 and 30 . Enzymatic digestion of such pulps by cellulases may generate glucose syrups of low pentose contents that are potential carbon sources for fermentation processes. Hydrolysates of plant biomass are usually produced using not only cellulases but also enzymes degrading hemicelluloses and pectin, and therefore contain mixtures of glucose and other sugars (Wilson 2009). Some of the latter (e.g., xylose, arabinose and galacturonic acid) are less efficiently converted by industrial microorganisms to ethanol and other valuable products than glucose (Edwards and DoranPeterson 2012) however, application of mixed microbial cultures enabled to increase ethanol yields from xylose (Chen 2011). Cellulosic pulps may be regarded as glucose-rich streams for bioethanol production not only because of the low contents of substances that reduce the digestibility of the cellulose fibers but also because of the relatively low price of 700-800 USD per one ton (World Pulp Monthly, January 2014). Moreover, these pulps are free of typical fermentation inhibitors, like furfural and 5-hydroxymethylfurfural, that are generated by many other pretreatment processes and which considerably reduce conversion yields (Stoutenburg et al. 2011). Thus kraft pulping may compete with other methods of lignocellulosic biomass pretreatment before enzymatic saccharification. Furthermore, the side products of kraft pulping (lignin-rich streams) are used to provide heat and electricity for paper mills that reduces the overall costs of processing (Chakar and Ragauskas 2004).

In this study, we attempted to assess the digestibility of cellulosic pulps produced by kraft pulping of poplar, birch, beech and pine woods and wheat straw, based on yields of glucose and other soluble reducing sugars released by cellulases and hemicellulases. Chopped wheat straw (size of $6 \mathrm{~mm}$ or less) and poplar wood chips (with particle size of $1.2-1.6 \mathrm{~mm}$ ) were the reference materials. Wheat straw and poplar wood are important raw materials not only for papermaking but also for the production of fuels, chemicals and energy. Their principal components are cellulose, hemicelluloses and lignin. Contents of these polymers depend on plant species and variety as well as cultivation conditions. For instance, according to Sun et al. (1996) wheat straw contained 35-40\% d.w. cellulose, and 30-35 \% d.w. hemicelluloses, mainly L-arabino(4-o-methyl-D-glucurono)-D-xylan. It also contained approximately $14 \%$ d.w. of strongly cross-linked lignin (Sun et al. 1997). The study of Ludot et al. (2014) revealed that lignin content in wheat straw was around $21.7 \%$ d.w. while contents of D-glucose, Dxylose, L-arabinose and uronic acids were 35.8, 21.5, 2.4 and $1.9 \%$ d.w., respectively. Poplar wood contained $24.8 \%$ d.w. lignin and $41.7 \%$ d.w. glucose, $14.6 \%$ d.w. D-xylose and $3.6 \%$ d.w. uronic acids. Hausser et al. (2013) reported that wheat straw contained $39 \%$ d.w. glucan and $29 \%$ d.w. pentosans (24\% xylan and $5 \%$ araban) while poplar wood chips contained $42 \%$ glucan and $15 \%$ xylan. According to data collected by Van Dyk and Pletschke (2012) cellulose, hemicellulose and lignin contents in wheat straw are as follows: $30-44,23-50$ and 7.7-17 \% d.w., respectively. Levels in a hybrid poplar reach 40, 22 and $24 \%$ d.w., respectively.

\section{Materials and methods}

Poplar woodchips, chopped wheat straw and cellulosic pulps

All the woodchips were obtained from wood after the inner and outer barks and knots had been mechanically removed. Poplar woodchips (particle size of $1.2-1.6 \mathrm{~mm}$ ) were prepared by drilling of larger pieces of poplar wood using an electric 6388AA Skil drill (Lowe's Co., USA) equipped with a Metabo drill (Poland) no 10 (10.0 $\mathrm{mm}$ in diameter). Then the chips were sieved through a series of sieves to separate the $1.2-1.6 \mathrm{~mm}$ particles. The chaff of wheat straw was obtained from stems of Triticum aestivum L., using a 
Ming-Lee ML-ST50 chaff cutter (China) equipped with a screening plate (hole diameter of $6 \mathrm{~mm}$ ). Only the fraction with the size of $6 \mathrm{~mm}$ or less was used in the experiment. Poplar cellulosic pulps of various Kappa numbers (15.4, 19.5, 22.4 and 24.2) were prepared by the sulfate method as described in (Modrzejewski et al. 1969) from woodchips $(20 \mathrm{~mm} \times 16 \mathrm{~mm} \times 8 \mathrm{~mm})$, containing $\quad 7-8 \%$ humidity. Beech, birch, pines and wheat straw pulps (Kappa numbers of 25.8, 28.3, 31.4, and 29.5, respectively) were prepared by the same method. The disintegrated materials were kept in hermetically closed vials to avoid any changes in the humidity before the treatment with $\mathrm{NaOH}$ and $\mathrm{Na}_{2} \mathrm{~S}$ solutions [at chips or straw: solvent ratio of 1:4 (w/v)], which were prepared freshly before the usage. Delignification processes were conducted in 2.51 stainless steel reactors with regulation of temperature. Suspensions of woodchips or chopped wheat straw were heated for 120 min to achieve the temperature of $160{ }^{\circ} \mathrm{C}$ and incubated at this temperature for the next $120 \mathrm{~min}$. Then the temperature was decreased to the ambient one using cold tap water and the insoluble residue was separated by filtration on Buchner funnel, washed several times with demineralized water and incubated overnight in demineralized water to remove residues of the alkali-soluble fractions. The solids were disintegrated for $3 \mathrm{~min}$ in a laboratory propeller pulp disintegrator (type R1 from Labor-meks, Poland), and the fibers were collected by centrifuging ( $300 \mathrm{rpm}$, $10 \mathrm{~min}$ ) and weighed. Triplicate samples of these fibers were analyzed for the humidity and residual lignin (Kappa number) contents. Yields of cellulosic pulps obtained by this method ranged from around 45 to $56 \%$ on a dry weight basis (Table 1) like in industrial conditions.

Industrial fines fraction

Residual fines fraction was taken from a technological line in one of Polish paper mill. Thirty liters of waste water containing the fines were taken from the wire tank, placed in a vessel and left for 30 min to sediment the fines. The upper water layer was discarded and the concentrated fines fraction was filtered to remove particles larger than $0.2 \mathrm{~mm}$. The humidity of the filtered fines fraction was $14-16 \%(\mathrm{w} / \mathrm{w})$. The size of particles was measured using a Kajaani FS-200 fiber-length analyzer and its maximal value was below $0.2 \mathrm{~mm}$.
Table 1 Kappa numbers and yields (on a dry weight basis) of cellulosic pulps obtained by the sulfate method from woodchips or wheat straw

\begin{tabular}{lll}
\hline Pulp & Kappa number & Yield (\% d.w.) \\
\hline Poplar & 15.4 & 54.5 \\
& 19.5 & 56.0 \\
& 22.4 & 55.4 \\
& 24.2 & 52.3 \\
Birch & 28.3 & 53.1 \\
Beech & 25.8 & 49.5 \\
Pine & 31.4 & 45.8 \\
Wheat straw & 29.5 & 56.5 \\
\hline
\end{tabular}

Enzyme preparations

Three commercial, industrial grade enzyme preparations NS-22086, NS-22119 and Ultraflomax, which were kindly supplied by Novozymes A/S (Denmark) and showed activities of cellulases and xylanases, were used in the study. Activities of these enzymes were assayed by the 3,5-dinitrosalicylic acid (DNS) method (Miller 1959) at $\mathrm{pH} 5.0$ and $50{ }^{\circ} \mathrm{C}$ for $0.5 \%$ carboxymethylcellulose and $0.5 \%$ birch xylan, respectively (reaction time of $5 \mathrm{~min}$ ). Activities of both the glycosidases were expressed as micromoles of reducing sugars released from the polysaccharide substrates in $1 \mathrm{~min}$ (U). Total reducing sugars and glucose concentrations in these enzyme preparations were assayed as described below.

Enzymatic hydrolysis

Enzymatic hydrolysis processes were conducted at $50{ }^{\circ} \mathrm{C}$, at either around 1.3 or $7.4 \%(\mathrm{w} / \mathrm{w})$ substrate concentration. In the first case, samples of the listed above substrates (around $0.3 \mathrm{~g}$ wet mass, $0.28 \mathrm{~g}$ d.w.) were suspended in $0.1 \mathrm{M}$ sodium-acetate buffer solu-

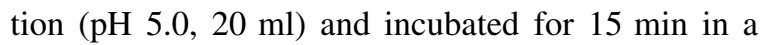
water bath at $50{ }^{\circ} \mathrm{C}$. Then $1 \mathrm{ml}$ aliquot of one of the three aforementioned enzyme preparations (Ultraflomax and NS-22119 were not diluted while NS-22086 was diluted sixfold in the same buffer) was added (with vigorous mixing) to each of these suspensions to initiate enzymatic digestion. When hydrolysis was carried out at substrate concentration of $7.4 \%(\mathrm{w} / \mathrm{w})$, samples of poplar pulp (30.1 g wet mass, $28.14 \mathrm{~g}$ d.w., 
Kappa number of 24.2) were mixed with $345 \mathrm{ml}$ of demineralized water and incubated for $15 \mathrm{~min}$ at $50{ }^{\circ} \mathrm{C}$ before addition of $3 \mathrm{ml}$ of NS-22086 preparation. All the hydrolysates were sampled just after addition of the enzyme (to determine initial concentrations of glucose and total reducing sugars) and after 1, 3, 6, 24, 48 and $72 \mathrm{~h}$ of the process (to follow the progress of enzymatic hydrolysis). All samples of enzymatic hydrolysates were filtered through a medium-fast filter paper and the filtrates were subjected to analyses. Dry weight of the insoluble residues after enzymatic hydrolysis was determined gravimetrically after drying to constant weight at $105{ }^{\circ} \mathrm{C}$. Microscopic observations of fibers subjected to enzymatic treatment were conducted at $200 \times$ magnification using a MPI3/SK12 PZO (Poland) optical microscope.

Analytical methods

Reducing sugars concentration was determined according to Miller using the alkaline DNS solution (1959). Mono- and disaccharide profiles of the hydrolysates were determined by HPLC using an Ultimata 3000 Dionex liquid chromatograph equipped with a Rezex RPM-Monosaccharide $\mathrm{Pb}^{2+}$ column $(8 \mu \mathrm{m}$, $7.8 \mathrm{~mm} \times 300 \mathrm{~mm}$ ) and a Shodex-RI-10 refractive index detector. The temperature of the column and RI detector was 80 and $40{ }^{\circ} \mathrm{C}$, respectively. Samples of hydrolysates were filtered through a nylon syringe filter $(0.45 \mu \mathrm{m})$ before HPLC analysis. The volume of injected samples was $10 \mu \mathrm{l}$. HPLC grade water (Sigma) was used as the mobile phase at a flow rate of $0.6 \mathrm{ml} / \mathrm{min}$. Results of sugar resolution were recorded over $35 \mathrm{~min}$. Glucose concentration was also determined according to Barham and Trinder (1972), using a commercial diagnostic kit employing glucose oxidase and peroxidase (Biomaxima, Poland). The assay was conducted according to the instruction from the manufacturer of the kit.

Both hydrolysis processes and analyses of the hydrolysates were carried out in at least triplicate. Their results are presented as mean \pm standard deviation (SD).

Yield calculations

The yield of glucose and total reducing sugars were calculated according to Kumar and Wyman (2009) with some modification:
Glucose yield $=$ glucose in hydrolysate $(\mathrm{g})$ $\times 0.9$ / initial dry weight of the sample $(\mathrm{g})$

Total reducing sugars yield

$=$ reducing sugars in hydrolysate

$\times 0.9$ / initial dry weight of the sample $(\mathrm{g})$

The same coefficient (0.9) was used in the calculations for all the reducing sugars quantified by HPLC because glucose was the dominating of them.

\section{Results}

Selection of enzyme preparation

Lignocellulosic materials are most often treated with cocktails of commercial preparations of endoglucanases, $\beta$-glucosidases and xylanases (Van Dyk and Pletschke 2012). To check if the similar results may be achieved using a single multienzyme preparation, containing cellulases and xylanases, we tested three multienzyme preparations NS-22086, NS-22119 and Ultraflomax (Table 2). Because NS-22086 showed several fold higher activity of cellulases and xylanases (per $1 \mathrm{ml}$ ) than the other two preparations, in the first experiment it was diluted sixfold in the $0.1 \mathrm{M}$ sodium acetate buffer $\mathrm{pH} 5.0$ (to maintain the $\mathrm{E}: \mathrm{S}$ ratio for cellulases at the similar level for the three tested multienzyme preparations). Each of these three enzyme preparations contained reducing sugars, including free glucose. For instance, their concentrations in NS-22086 were $68.6 \mathrm{mg} / \mathrm{ml}$ and $42.0 \mathrm{mg} / \mathrm{ml}$ (61.22\% total reducing sugars), respectively. Concentrations of these sugars in enzyme preparations were taken into consideration when the yields of enzymatic saccharification of the pulps, woodchips and straw were calculated.

Table 2 Activities of cellulases and xylanases in NS-22086, NS-22119 and Ultraflomax preparations $\left(50{ }^{\circ} \mathrm{C}, \mathrm{pH} 5.0\right)$

\begin{tabular}{llll}
\hline $\begin{array}{l}\text { Type of } \\
\text { enzyme }\end{array}$ & $\begin{array}{l}\text { NS-22086 } \\
(\mathrm{U} / \mathrm{ml})\end{array}$ & $\begin{array}{l}\text { NS-22119 } \\
(\mathrm{U} / \mathrm{ml})\end{array}$ & $\begin{array}{l}\text { Ultraflomax } \\
(\mathrm{U} / \mathrm{ml})\end{array}$ \\
\hline Cellulases & 80.58 & 12.1 & 13.5 \\
Xylanases & 192.48 & 19.7 & 53.3 \\
\hline
\end{tabular}


Comparison of results of the pine cellulosic pulp (Kappa number of 31.4, concentration of around $1.3 \% \mathrm{w} / \mathrm{w})$ digestion by the three enzyme preparations revealed that the highest amounts of glucose and other reducing sugars were obtained using the preparation NS-22086 (Table 3). In this case the yields of glucose and reducing sugars reached approximately 72 and $90 \%$ on a pulp's dry weight basis, respectively while for the other two enzyme preparations the reducing sugars yields varied from around $19 \%$ d.w. to around $47 \%$ d.w., and glucose accounted for more than $96 \%$ total reducing sugars. The yield of pine woodchips conversion by the sulfate method into the pulp was $45.8 \%$ on a dry weight basis and therefore glucose and total reducing sugars yields from the wood reached only around 33 and $41 \%$ d.w., respectively, for the preparation NS-22086.

The highly advanced degradation of the pine pulp by the preparation NS-22086 was confirmed by microscopic observations of cellulosic fibers contained in the pulp (Fig. 1), which showed that their dimensions gradually decreased during $48 \mathrm{~h}$ hydrolysis.

Further experiments on enzymatic hydrolysis of cellulosic pulps were conducted using only the preparation NS-22086. It was diluted sixfold before addition to the substrates [when their concentration was around $1.3 \%(\mathrm{w} / \mathrm{w})]$, to reduce amounts of sugars added into the reaction mixture with the enzyme preparation. Glucose and other simple sugars contained in enzyme preparations may contribute to inhibition of cellulases and hemicellulases in later stages of hydrolysis when concentration of its products is increased.

For substrate concentrations around $1.3 \%(\mathrm{w} / \mathrm{w})$, all the hydrolysis processes were conducted at enzyme: substrate ratio of around $13.43 \mathrm{U}: 0.3 \mathrm{~g} \mathrm{~d} . \mathrm{w}$. for cellulases, and $32.08 \mathrm{U}: 0.3 \mathrm{~g}$ d.w. for xylanases. This relatively low substrate concentration enables to avoid end-product inhibition and estimate the maximum substrate digestibility (Galbe and Zacchi 2007). Therefore, enzymatic hydrolysis of pretreated biomass, performed at this substrate concentration is one of methods used for the assessment of pretreatment. However, this substrate concentration is too low to achieve sufficiently high concentrations of glucose and other fermentable sugars in hydrolysates of polysaccharides.

Enzymatic hydrolysis of a poplar pulp

Availability of poplar wood and pulps makes them attractive substrates for biofuel production. To determine the digestibility of a poplar pulp with the Kappa number of 24.2, it was treated with the preparation NS22086. Concentrations of glucose and total reducing sugars in the hydrolysate were monitored over $48 \mathrm{~h}$ despite their low increase after the first $6 \mathrm{~h}$ when the yields of glucose and reducing sugars achieved around 62 and $80 \%$ d.w., respectively (Table 4). The pulp was almost completely converted into soluble sugars within $24 \mathrm{~h}$. Sugars released into the liquid fraction were identified and quantified by HPLC (Table 5). Glucose accounted for 70-80 \% total reducing sugars from the beginning of hydrolysis. HPLC analyses revealed that apart from glucose to cellobiose the hydrolysates contained some xylose and mannose, released by xylanases and mannan-degrading hydrolases from hemicellulose residues in the pulp. The increasing content of glucose and decreasing level of cellobiose present among hydrolysis products provide evidence of the simultaneous action of cellobiohydrolase and $\beta$-glucosidase. However, the low increase in glucose concentration and almost constant level of cellobiose after the first $6 \mathrm{~h}$ suggests that $\beta$-glucosidase activity was inhibited by glucose. Inhibition of cellobiohydrolases (EC 3.2.1.91) and endoglucanases
Table 3 Glucose concentrations and total reducing sugars yields in enzymatic hydrolysates of the pine cellulosic pulp (Kappa number of 31.4) for the three tested enzyme preparations $\left(50^{\circ} \mathrm{C}, \mathrm{pH} 5.0\right.$, $48 \mathrm{~h})$

\begin{tabular}{|c|c|c|c|c|c|}
\hline \multirow[t]{2}{*}{$\begin{array}{l}\text { Enzyme } \\
\text { preparation }\end{array}$} & \multirow[t]{2}{*}{$\begin{array}{l}\text { Glucose concentration } \\
(\mathrm{mg} / \mathrm{ml})\end{array}$} & \multicolumn{2}{|c|}{ Mean glucose yield } & \multicolumn{2}{|c|}{$\begin{array}{l}\text { Mean reducing sugars } \\
\text { yield }\end{array}$} \\
\hline & & $\begin{array}{l}\% \text { d.w. } \\
\text { pulp }\end{array}$ & $\begin{array}{l}\% \text { d.w. } \\
\text { wood }\end{array}$ & $\begin{array}{l}\% \text { d.w. } \\
\text { pulp }\end{array}$ & $\begin{array}{l}\% \text { d.w. } \\
\text { wood }\end{array}$ \\
\hline NS-22086 & $11.41 \pm 0.23$ & 71.79 & 32.88 & 90.00 & 41.22 \\
\hline NS-22119 & $3.06 \pm 0.18$ & 18.23 & 8.35 & 18.86 & 8.64 \\
\hline Ultraflomax & $7.54 \pm 0.21$ & 46.45 & 21.27 & 46.54 & 21.32 \\
\hline
\end{tabular}



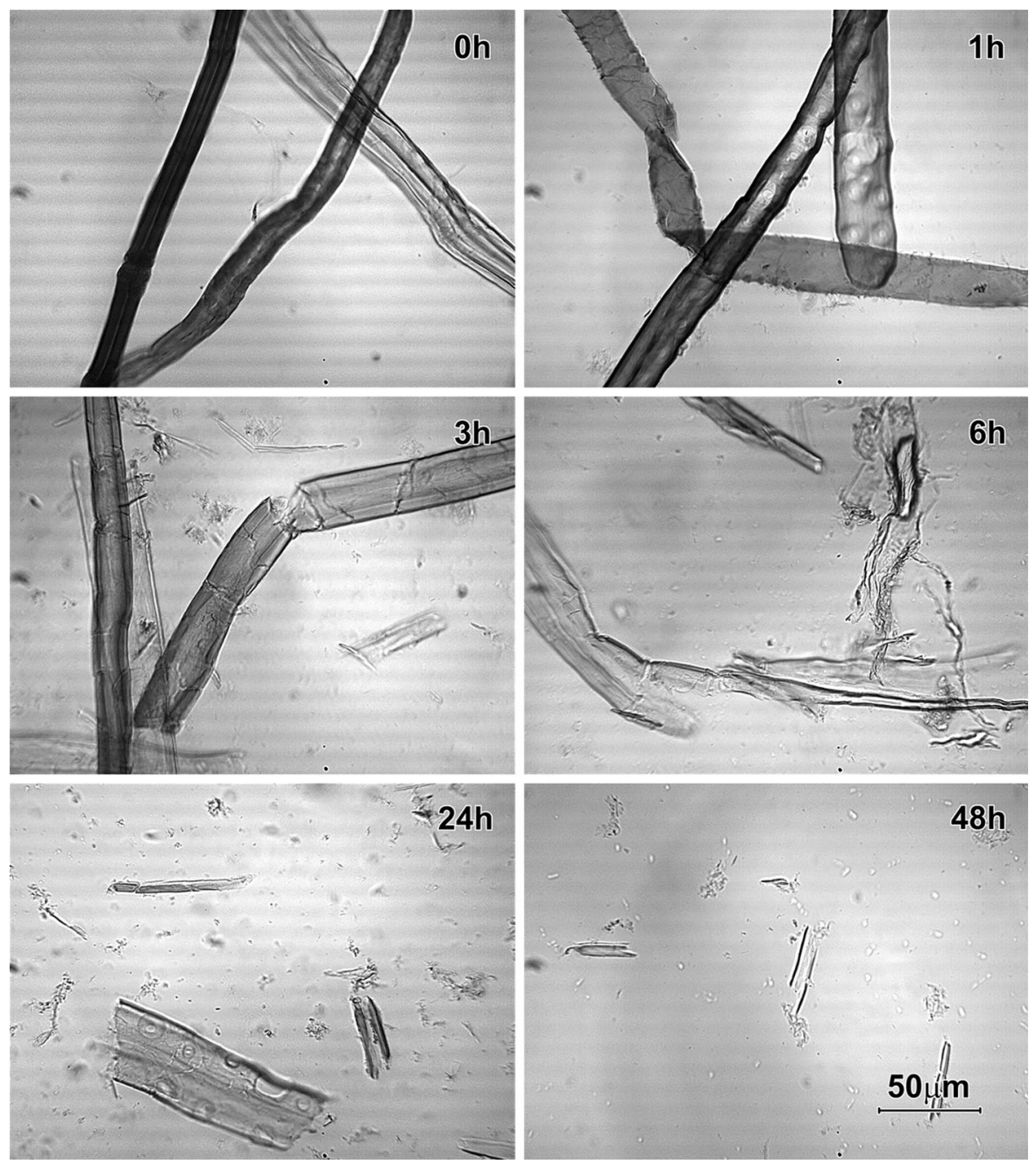

Fig. 1 Microscopic images at $\times 200$ magnification showing the gradual degradation of pine cellulosic pulp fibers during $48 \mathrm{~h}$ hydrolysis mediated by the preparation NS-22086 $\left(50{ }^{\circ} \mathrm{C}, \mathrm{pH} 5.0\right)$

Table 4 Changes in concentrations of glucose and total reducing sugars and their yields during enzymatic hydrolysis of the poplar pulp with Kappa number of $24.2\left(50^{\circ} \mathrm{C}\right.$, pH 5.0, $\left.48 \mathrm{~h}\right)$, catalyzed by the preparation NS-22086

\begin{tabular}{|c|c|c|c|c|c|c|}
\hline \multirow[t]{2}{*}{ Time (h) } & \multirow{2}{*}{$\begin{array}{l}\text { Glucose } \\
\text { concentration } \\
(\mathrm{mg} / \mathrm{ml})\end{array}$} & \multicolumn{2}{|c|}{ Mean glucose yield } & \multirow{2}{*}{$\begin{array}{l}\text { Total reducing sugars } \\
\text { concentration }(\mathrm{mg} / \mathrm{ml})\end{array}$} & \multicolumn{2}{|c|}{ Mean reducing sugars yield } \\
\hline & & $\%$ d.w. pulp & $\%$ d.w. wood & & $\%$ d.w. pulp & $\%$ d.w. wood \\
\hline 1 & 4.52 & 26.75 & 13.99 & 6.47 & 37.84 & 19.79 \\
\hline 3 & 7.83 & 47.89 & 20.05 & 10.59 & 64.14 & 33.55 \\
\hline 6 & 10.02 & 61.87 & 32.36 & 13.10 & 80.17 & 41.93 \\
\hline 24 & 12.56 & 78.05 & 40.82 & 16.08 & 99.20 & 51.88 \\
\hline 48 & 12.96 & 80.62 & 42.16 & 16.62 & 100 & 52.3 \\
\hline
\end{tabular}

(EC 3.2.1.4) by cellobiose and glucose as well as inhibition of $\beta$-glucosidases (EC 3.2.1.21) by glucose considerably reduce yields of fermentable sugars derived from plant biomass (Andrić et al. 2010; Miao et al. 2012). To overcome this problem, enzymatic hydrolysis processes are either conducted in 
Table 5 Mean percentage contents of glucose, cellobiose, xylose and mannose among mono- and disaccharides contained in hydrolysates of the poplar pulp with the Kappa number of 24.2

\begin{tabular}{lllll}
\hline $\begin{array}{l}\text { Time } \\
(\mathrm{h})\end{array}$ & $\begin{array}{l}\text { Glucose } \\
(\% \mathrm{w} / \mathrm{w})\end{array}$ & $\begin{array}{l}\text { Cellobiose } \\
(\% \mathrm{w} / \mathrm{w})\end{array}$ & $\begin{array}{l}\text { Xylose } \\
(\% \mathrm{w} / \mathrm{w})\end{array}$ & $\begin{array}{l}\text { Mannose } \\
(\% \mathrm{w} / \mathrm{w})\end{array}$ \\
\hline 1 & 69.93 & 19.45 & 9.41 & 1.21 \\
3 & 73.95 & 15.27 & 10.04 & 0.73 \\
6 & 76.49 & 12.11 & 10.64 & 0.75 \\
24 & 78.10 & 10.55 & 10.64 & 0.72 \\
48 & 77.96 & 11.15 & 10.27 & 0.62 \\
\hline
\end{tabular}

membrane reactors enabling separation of simple sugars from much larger molecules of enzymes and polysaccharides or the separated hydrolysis and fermentation (SHF) is replaced by the simultaneous saccharification and fermentation (SSF; Van Dyk and Pletschke 2012).

Results shown in Tables 4 and 5 were correlated with apparent changes in the appearance of fibers contained in the poplar pulp, which was digested by the preparation NS-22086. Microscopic images shown in Fig. 2, which present successive steps of gradual deconstruction of poplar cellulosic fibers, provide evidence that the attack of cellulolytic and hemicellulolytic enzymes caused their complete degradation within $48 \mathrm{~h}$.

Enzymatic hydrolysis of poplar pulps with different Kappa numbers

Because of the promising results of enzymatic hydrolysis of the poplar pulp with the Kappa number of 24.2, also three other poplar pulps with Kappa numbers of 15.4, 19.5 and 22.4 were subjected to enzymatic hydrolysis under the same conditions. Concentrations and yields of glucose and total reducing sugars in their hydrolysates are presented in Table 6 . The pulps were completely digested within $48 \mathrm{~h}$.

Results of HPLC analysis of the hydrolysates are shown in Table 7. Because of the similar degree of delignification and purification of the 4 compared poplar pulps, the composition of their $48 \mathrm{~h}$ hydrolysates was virtually the same, it means the dominating of four detectable sugars was glucose $(77-78 \% \mathrm{w} / \mathrm{w})$ while xylose level was around $10-13 \% \mathrm{w} / \mathrm{w}$, alike the concentration of cellobiose (around $11 \% \mathrm{w} / \mathrm{w}$ ). Amounts of mannose varied between around 0.2 and
$0.6 \% \mathrm{w} / \mathrm{w}$ of the sum of four sugars. The presence of cellobiose suggests inhibition of $\beta$-glucosidase by glucose contained in the four hydrolysates. Despite the presence of residual cellobiose, the around $80 \%$ glucose yield (on a dry weight basis) from poplar pulps with Kappa numbers of 15.4-4.2, corresponding to $42-45 \%$ glucose yield from poplar wood d. w., was satisfying.

Enzymatic hydrolysis of poplar woodchips, wheat straw and cellulosic pulps of other origins

To characterize hydrolytic potential of the multienzyme preparation NS-22086, also beech, birch and wheat straw pulps as well as poplar woodchips and chopped wheat straw were subjected to hydrolysis apart from the poplar and pine pulps (Table 8). The poplar woodchips and wheat straw chaff were obtained by mechanical disintegration and were not subjected to any other pretreatment before the hydrolysis. They played the role of reference lignincontaining materials.

The poplar woodchips and chopped wheat straw, which were subjected to enzymatic digestion for $72 \mathrm{~h}$ were saccharified in around 16 and $23 \%$ d.w. (glucose yields were around 5.3 and $14 \%$ d.w., respectively) while the cellulosic pulps were completely converted to glucose and other reducing sugars within $48 \mathrm{~h}$. Thus the pretreatment of poplar wood and wheat straw by the sulfate method increased glucose yields from enzymatic hydrolysis by around 7.9 and 3.1-fold respectively.

Mono- and disaccharide profiles of these hydrolysates that were determined by HPLC are shown in Table 9. Glucose accounted for $73-79 \% \mathrm{w} / \mathrm{w}$ of the sum of the quantified sugars in the hydrolysates of the cellulosic pulps, irrespective of their origin, while in the hydrolysates of chopped wheat straw and poplar woodchips its contents were around 62 and $38 \% \mathrm{w} / \mathrm{w}$, respectively. The relatively high levels of cellobiose in hydrolysates of the pulps (around $10 \% \mathrm{w} / \mathrm{w}$ ) and poplar woodchips (around $44 \% \mathrm{w} / \mathrm{w})$ suggest inhibition of $\beta$-glucosidase activity by glucose. Digests of pulps from wheat straw, and beech, birch and poplar woods contained more than $10 \% \mathrm{w} / \mathrm{w}$ xylose while its contents in the hydrolysates of pine pulp and wheat straw chaff were only around $3 \% \mathrm{w} / \mathrm{w}$. The latter hydrolysate contained around $33 \% \mathrm{w} / \mathrm{w}$ mannose whereas the 

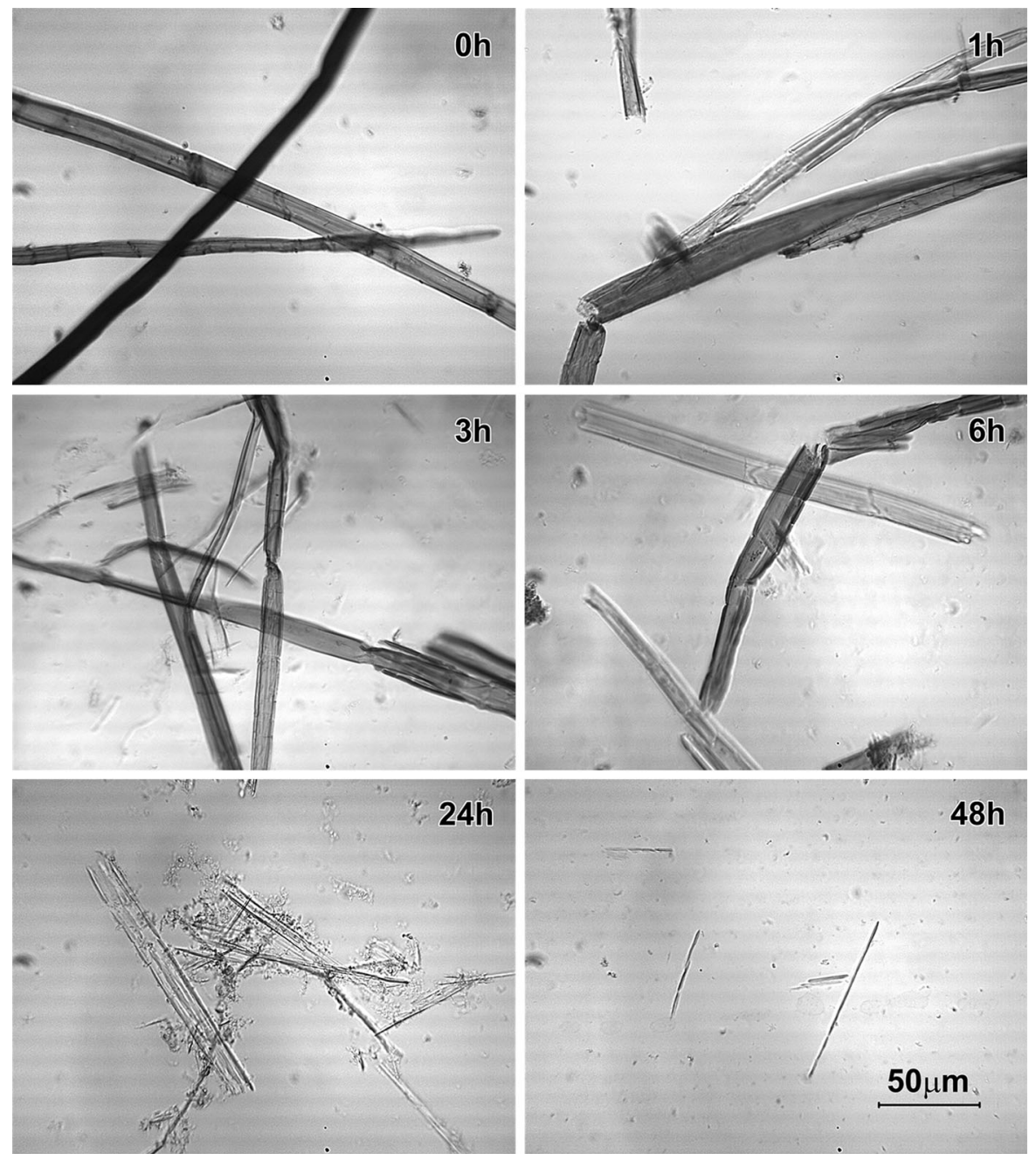

Fig. 2 Microscopic images at $\times 200$ magnification showing the gradual degradation of poplar cellulosic pulp fibers during $48 \mathrm{~h}$ hydrolysis mediated by the preparation NS-22086 $\left(50{ }^{\circ} \mathrm{C}, \mathrm{pH} 5.0\right)$

Table 6 The effect of the Kappa number of poplar pulps on concentrations and yields of glucose and total reducing sugars in enzymatic hydrolysates $\left(50{ }^{\circ} \mathrm{C}, \mathrm{pH} 5.0,48 \mathrm{~h}\right)$

\begin{tabular}{|c|c|c|c|c|c|c|}
\hline \multirow[t]{2}{*}{ Kappa number } & \multirow{2}{*}{$\begin{array}{l}\text { Glucose } \\
\text { concentration } \\
(\mathrm{mg} / \mathrm{ml})\end{array}$} & \multicolumn{2}{|c|}{ Mean glucose yield } & \multirow{2}{*}{$\begin{array}{l}\text { Total reducing sugars } \\
\text { concentration }(\mathrm{mg} / \mathrm{ml})\end{array}$} & \multicolumn{2}{|c|}{ Mean reducing sugars yield } \\
\hline & & $\%$ d.w. pulp & $\%$ d.w. wood & & $\%$ d.w. pulp & $\%$ d.w. wood \\
\hline 15.4 & $12.67 \pm 0.15$ & 79.0 & 43.1 & $16.51 \pm 0.18$ & 100 & 54.5 \\
\hline 19.5 & $12.90 \pm 0.28$ & 80.5 & 45.1 & $16.49 \pm 0.36$ & 100 & 56.0 \\
\hline 22.4 & $13.31 \pm 0.20$ & 81.8 & 45.3 & $17.19 \pm 0.25$ & 100 & 55.4 \\
\hline 24.2 & $12.96 \pm 0.12$ & 80.6 & 42.2 & $16.62 \pm 0.15$ & 100 & 52.3 \\
\hline
\end{tabular}

hydrolysates of pulps contained only up to $1.5 \% \mathrm{w} / \mathrm{w}$ of this sugar. Also the hydrolysate of poplar woodchips was rich in mannose (around $15 \% \mathrm{w} / \mathrm{w}$ of the quantified five sugars). Much lower mannose concentration in the hydrolysates of pulps suggests that processing of the woodchips and wheat straw by the sulfate method causes a decrease in the content of mannan. 
Table 7 Mean percentage contents of glucose, cellobiose, xylose and mannose among mono- and disaccharides contained in hydrolysates of the poplar pulps with the Kappa numbers varying from 15.4 to $24.2\left(50{ }^{\circ} \mathrm{C}, \mathrm{pH} 5.0,48 \mathrm{~h}\right)$

\begin{tabular}{lllll}
\hline $\begin{array}{l}\text { Kappa } \\
\text { number }\end{array}$ & $\begin{array}{l}\text { Glucose } \\
(\% \mathrm{w} / \mathrm{w})\end{array}$ & $\begin{array}{l}\text { Cellobiose } \\
(\% \mathrm{w} / \mathrm{w})\end{array}$ & $\begin{array}{l}\text { Xylose } \\
(\% \mathrm{w} / \mathrm{w})\end{array}$ & $\begin{array}{l}\text { Mannose } \\
(\% \mathrm{w} / \mathrm{w})\end{array}$ \\
\hline 15.4 & 76.74 & 10.37 & 12.71 & 0.18 \\
19.5 & 78.21 & 11.30 & 10.00 & 0.49 \\
22.4 & 77.42 & 10.56 & 11.73 & 0.29 \\
24.2 & 77.96 & 11.15 & 10.27 & 0.62 \\
\hline
\end{tabular}

Enzymatic hydrolysis of the waste fines fraction

Because of the encouraging results of enzymatic hydrolysis of the tested cellulosic pulps from various plant sources, the NS-22086 preparation was also used to hydrolyze the fines fraction from the Mondi Świecie

Table 8 Concentrations and yields of glucose and total reducing sugars in enzymatic hydrolysates of poplar, pine, beech, birch and wheat straw pulps, chopped wheat straw and paper-mill. Its samples were suspended in either $0.1 \mathrm{M}$ sodium-acetate buffer solution $\mathrm{pH} 5.0$ or demineralized water. Irrespective of the solvent, the fraction was almost completely saccharified within $24 \mathrm{~h}$ (Table 10). Glucose accounted for around $83 \% \mathrm{w} / \mathrm{w}$ of the quantified sugars while cellobiose content was around $9 \% \mathrm{w} / \mathrm{w}$ (Table 11), like in the hydrolysates of cellulosic pulps. Levels of xylose, mannose and arabinose were below $5 \% \mathrm{w} / \mathrm{w}$. The advantageous composition of enzymatic hydrolysates of fines renders them potential sugar feedstocks for fermentations.

Enzymatic hydrolysis of the poplar pulp at $7.4 \%$ (w/w) concentration

As it was mentioned above, around $1.3 \%(\mathrm{w} / \mathrm{w})$ substrate concentration is too low to achieve sufficiently high concentrations of glucose and other

poplar woodchips $\left(50^{\circ} \mathrm{C}, \mathrm{pH} 5.0,48 \mathrm{~h}\right.$, the poplar woodchips and chopped wheat straw were digested for $72 \mathrm{~h}$ )

\begin{tabular}{|c|c|c|c|c|c|c|c|}
\hline \multirow[t]{2}{*}{ Substrate } & \multirow[t]{2}{*}{$\begin{array}{l}\text { Kappa } \\
\text { number }\end{array}$} & \multirow{2}{*}{$\begin{array}{l}\text { Glucose } \\
\text { concentration } \\
(\mathrm{mg} / \mathrm{ml})\end{array}$} & \multicolumn{2}{|c|}{ Mean glucose yield } & \multirow{2}{*}{$\begin{array}{l}\text { Total reducing } \\
\text { sugars concentration } \\
(\mathrm{mg} / \mathrm{ml})\end{array}$} & \multicolumn{2}{|c|}{$\begin{array}{l}\text { Mean reducing } \\
\text { sugars yield }\end{array}$} \\
\hline & & & $\begin{array}{l}\% \text { d.w. } \\
\text { pulp }\end{array}$ & $\begin{array}{l}\% \text { d.w. } \\
\text { wood or } \\
\text { straw }\end{array}$ & & $\begin{array}{l}\% \text { d.w. } \\
\text { pulp }\end{array}$ & $\begin{array}{l}\% \text { d.w. } \\
\text { wood or } \\
\text { straw }\end{array}$ \\
\hline Poplar pulp & 24.2 & $12.96 \pm 0.12$ & 80.62 & 42.16 & $16.62 \pm 0.15$ & 100 & 52.30 \\
\hline Pine pulp & 31.4 & $11.41 \pm 0.23$ & 70.72 & 32.39 & $14.47 \pm 1.65$ & 88.92 & 40.73 \\
\hline Beech pulp & 25.8 & $12.62 \pm 0.15$ & 78.98 & 39.10 & $16.86 \pm 1.04$ & 100 & 49.50 \\
\hline Birch pulp & 28.3 & $11.98 \pm 0.30$ & 74.87 & 39.76 & $15.90 \pm 2.49$ & 98.71 & 52.42 \\
\hline Wheat straw pulp & 29.5 & $12.96 \pm 0.07$ & 77.99 & 44.06 & $17.67 \pm 0.13$ & 100 & 56.50 \\
\hline Chopped wheat straw & n.d.* & $2.67 \pm 0.04$ & - & 14.4 & $4.32 \pm 0.10$ & - & 23.25 \\
\hline Poplar woodchips $(1.6-2.0 \mathrm{~mm})$ & n.d.* & $1.14 \pm 0.15$ & - & 5.33 & $2.96 \pm 0.41$ & - & 15.69 \\
\hline
\end{tabular}

* Not determined

Table 9 Mean percentage contents of glucose, cellobiose, xylose, arabinose and mannose among mono- and disaccharides contained in hydrolysates of tested pulps and wheat straw

\begin{tabular}{|c|c|c|c|c|c|}
\hline Substrate & $\begin{array}{l}\text { Glucose } \\
\text { (\% d.w.) }\end{array}$ & $\begin{array}{l}\text { Cellobiose } \\
\text { (\% d.w.) }\end{array}$ & $\begin{array}{l}\text { Xylose } \\
\text { (\% d.w.) }\end{array}$ & $\begin{array}{l}\text { Arabinose } \\
\text { (\% d.w.) }\end{array}$ & $\begin{array}{l}\text { Mannose } \\
\text { (\% d.w.) }\end{array}$ \\
\hline Poplar pulp & 77.96 & 11.15 & 10.27 & - & 0.62 \\
\hline Pine pulp & 78.88 & 12.54 & 3.45 & 3.59 & 1.54 \\
\hline Beech pulp & 74.86 & 11.08 & 13.31 & - & 0.75 \\
\hline Birch pulp & 75.36 & 11.46 & 12.29 & 0.34 & 0.54 \\
\hline Wheat straw pulp & 73.33 & 8.98 & 16.26 & 1.06 & 0.36 \\
\hline Wheat straw chaff & 61.85 & 1.91 & 3.38 & - & 32.86 \\
\hline Poplar woodchips $(1.2-1.6 \mathrm{~mm})$ & 38.45 & 43.83 & 1.49 & 1.46 & 14.76 \\
\hline
\end{tabular}


Table 10 Concentrations and yields of glucose and total reducing sugars in the fine cellulosic fraction hydrolysates $\left(50{ }^{\circ} \mathrm{C}\right.$, $\mathrm{pH} 5.0$, $24 \mathrm{~h})$

\begin{tabular}{lllll}
\hline Solvent & $\begin{array}{l}\text { Glucose } \\
\text { concentration }(\mathrm{mg} / \mathrm{ml})\end{array}$ & $\begin{array}{l}\text { Mean glucose } \\
\text { yield }(\% \text { d.w.) }\end{array}$ & $\begin{array}{l}\text { Total reducing } \\
\text { sugars concentration } \\
(\mathrm{mg} / \mathrm{ml})\end{array}$ & $\begin{array}{l}\text { Mean reducing } \\
\text { sugars yield }(\% \text { d.w.) }\end{array}$ \\
\hline $0.1 \mathrm{M}$ buffer pH 5.0 & 12.10 & 74.11 & 14.43 & 87.48 \\
Demineralized water & 11.87 & 72.66 & 14.33 & 86.85 \\
\hline
\end{tabular}

Table 11 Mean percentage contents of glucose, cellobiose, xylose, arabinose and mannose (in their sum) in hydrolysates of the waste fines fraction

\begin{tabular}{llllll}
\hline Solvent & $\begin{array}{l}\text { Glucose } \\
(\% \text { w.w. })\end{array}$ & $\begin{array}{l}\text { Cellobiose } \\
(\% \text { w.w. })\end{array}$ & $\begin{array}{l}\text { Xylose } \\
(\% \text { w.w. })\end{array}$ & $\begin{array}{l}\text { Mannose } \\
(\% \text { w.w. })\end{array}$ & $\begin{array}{l}\text { Arabinose } \\
(\% \text { w.w. })\end{array}$ \\
\hline 0.1 M buffer pH 5.0 & 83.81 & 8.80 & 3.20 & 4.18 & n.d. \\
Demineralized water & 82.80 & 9.06 & 4.55 & 0.61 & 2.99 \\
\hline
\end{tabular}

Table 12 Results of the two-step poplar pulp hydrolysis [Kappa number of $24.2,50{ }^{\circ} \mathrm{C}, 48 \mathrm{~h}$ each step, substrate concentrations of around 7.4 and $6.6 \%(\mathrm{w} / \mathrm{w})$ in the first and second step, respectively]

\begin{tabular}{|c|c|c|c|c|c|c|c|}
\hline \multirow[t]{2}{*}{ Step } & \multirow{2}{*}{$\begin{array}{l}\text { Mean glucose } \\
\text { concentration } \\
(\mathrm{mg} / \mathrm{ml})\end{array}$} & \multicolumn{2}{|l|}{ Glucose yield } & \multirow{2}{*}{$\begin{array}{l}\text { Mean reducing } \\
\text { sugars concentration } \\
(\mathrm{mg} / \mathrm{ml})\end{array}$} & \multicolumn{2}{|c|}{ Total reducing sugars yield } & \multirow{2}{*}{$\begin{array}{l}\text { Insoluble residue } \\
\% \text { d.w. pulp }\end{array}$} \\
\hline & & $\%$ d.w. pulp & $\%$ d.w. wood & & $\%$ d.w. pulp & $\%$ d.w. wood & \\
\hline I & 62.1 & 47.65 & 24.92 & 63.8 & 49.00 & 25.63 & 46.47 \\
\hline Washing & 70.0 & 8.96 & 4.69 & 72.0 & 9.21 & 4.82 & 41.79 \\
\hline II & 13.1 & 4.48 & 2.34 & 16.3 & 5.56 & 2.91 & 36.23 \\
\hline Total & - & 61.09 & 31.95 & - & 63.77 & 33.36 & 36.23 \\
\hline
\end{tabular}

fermentable sugars in hydrolysates of polysaccharides. Therefore, enzymatic hydrolysis of the poplar pulp (Kappa number of 24.2) was also conducted at its higher concentration (around $7.4 \% \mathrm{w} / \mathrm{w}$, it was the highest initial concentration of this pulp at which mixing of the dense slurry was possible) that enabled to increase glucose concentration in the hydrolysate from around $13 \mathrm{mg} / \mathrm{ml}$ to above $62 \mathrm{mg} / \mathrm{ml}$ (Table 12). In this case, hydrolysis was carried out at enzyme: substrate ratio of around 8.06 U: $1 \mathrm{~g}$ d.w. for cellulases and 19.25 U: $1 \mathrm{~g}$ d.w. for xylanases (around $1 \mathrm{ml}$ of the NS-22086 preparation per $10 \mathrm{~g} \mathrm{d.w}$. pulp). The dense suspension of the pulp in demineralized water was thoroughly mixed with the enzyme preparation just after its addition and the process was conducted for $48 \mathrm{~h}$ at $50{ }^{\circ} \mathrm{C}$ with intermittent mixing. The yield of glucose from the first step was almost $48 \%$ d.w. of the pulp (around $25 \%$ d.w. of poplar wood). The insoluble residue was washed twice with demineralized water to remove soluble sugars adsorbed to the insoluble fraction that increased the yield of glucose by around $9 \%$ d.w. of the pulp. The yield of glucose from the second step of hydrolysis (conducted in the same conditions as the first one with an exception of around $6.6 \% \mathrm{w} / \mathrm{w}$ substrate concentration) was only around $4.5 \%$ d.w. of the pulp. The total glucose yield was around $61 \%$ d.w. (around $57 \%$ d.w. from the first step and washing) while the insoluble fraction accounted for around $36 \%$ of the poplar pulp dry weight. Mono- and disaccharide profiles of the hydrolysates obtained in the first and second step of the hydrolysis are shown in Table 13. Thus one-step enzymatic hydrolysis of $10 \mathrm{~kg}$ d.w. of the poplar pulp, conducted at its around $7.4 \% \mathrm{w} / \mathrm{w}$ initial concentration and mediated by 11 of NS-22086 preparation, may produce around $5.7 \mathrm{~kg}$ glucose. Its fermentation may yield around $2.9 \mathrm{~kg}$ ethanol (theoretical yield of $0.512 \mathrm{~g}$ EtOH from $1 \mathrm{~g}$ glucose). It means that conversion of $10 \mathrm{~kg}$ d.w. of poplar woodchips via kraft pulping 
Table 13 Mean percentage contents of glucose, cellobiose and arabinose among mono- and disaccharides contained in the poplar pulp hydrolysates from the two-step process [Kappa number of $24.2,50{ }^{\circ} \mathrm{C}, 48 \mathrm{~h}$ each step, substrate concentrations of around 7.4 and $6.6 \%(\mathrm{w} / \mathrm{w})$ in the first and second step, respectively]

\begin{tabular}{llll}
\hline Step & $\begin{array}{l}\text { Glucose } \\
(\% \mathrm{w} / \mathrm{w})\end{array}$ & $\begin{array}{l}\text { Cellobiose } \\
(\% \mathrm{w} / \mathrm{w})\end{array}$ & $\begin{array}{l}\text { Arabinose } \\
(\% \mathrm{w} / \mathrm{w})\end{array}$ \\
\hline $\mathrm{I}$ & 97.31 & 1.40 & 1.29 \\
$\mathrm{II}$ & 80.46 & 7.61 & 1.60 \\
\hline
\end{tabular}

combined with the enzymatic hydrolysis may yield around $1.5 \mathrm{~kg}$ ethanol. Another product will be energy derived from incineration of the lignin-rich fraction from the kraft pulping. Also the insoluble residue from enzymatic digestion may be burnt.

Noteworthy, the hydrolysates of cellulosic pulps obtained in this work exhibited residual activities of cellulases and xylanases (around $80 \%$ of the initial ones). These enzymes may be separated from much smaller molecules of mono- and disaccharides using membranes, concentrated and reused for hydrolysis of cellulosic pulps. This may reduce the overall process costs.

Kraft pulping versus other pretreatment methods

Like other pretreatment methods, kraft pulping of recalcitrant lignocellulosic biomass ensures partial removal or disruption of lignin before enzyme-mediated conversion to fermentable sugars. Apart from lignin also a part of hemicelluloses is removed however, both these fractions are not lost as wastes but used to generate heat or electricity. Glucose yields obtained in this work from the poplar wood (around $42 \%$ d.w. wood) and wheat straw (around $44 \%$ d.w. straw) were equivalent to cellulose contents in these raw materials. Van Dyk and Pletschke (2012) reviewed reports of various conversion processes, including saccharification of pretreated poplar wood and wheat straw, catalyzed by mixtures of enzymes. The highest glucose yields from poplar wood (around $85 \%$ of glucose contained in the raw material) were achieved using either dilute acid or ionic liquid pretreatment. In case of wheat straw pretreated by dilute sulfuric acid and steam explosion, the yield of glucose from glucan was around $51 \%$. A new method enabling efficient conversion of lignocellulosic biomass, including poplar wood and wheat straw, is transglycosidation of hemicelluloses and cellulose to valuable alkyl pentosides and glucosides that are biodegradable surfactants (Ludot et al. 2014). Apart from these compounds this method yields cellulose-rich residue characterized by the high digestibility.

\section{Conclusions}

Cellulosic pulps from wood (poplar, pine, beech, birch) and wheat straw as well as the waste fines from paper mill were found to be easily digestible substrates for production of high-glucose hydrolysates (glucose content above $73 \%$ soluble sugars, glucose yields above $40 \%$ d.w. wood or straw) when treated with a suitable preparation of cellulases and hemicellulases, like the NS-22086 preparation from Novozymes, which also partly degraded poplar woodchips and chopped wheat straw (glucose and total reducing sugar yields of around 5.3 and $14 \%$ d.w., and around 16 and $23 \%$ d.w., respectively). The presence of glucose and cellobiose among hydrolysis products provides evidence that the NS-22086 preparation contains cellobiohydrolase and $\beta$-glucosidase apart from endoglucanase while the occurrence of free xylose, mannose and arabinose in the hydrolysates proves that it contains relevant hemicellulases. The kraft pulping process was found to be a suitable method of lignocellulosic biomass pretreatment before enzymatic hydrolysis, ensuring the high digestibility of various types of cellulosic pulps.

Acknowledgments Part of the research was financially supported by project N N309 706340 funded by National Science Centre (NCN, Poland) and by project PBS1/A8/16/ 2013 funded by National Centre for Research and Development (NCBiR, Poland).

Open Access This article is distributed under the terms of the Creative Commons Attribution License which permits any use, distribution, and reproduction in any medium, provided the original author(s) and the source are credited.

\section{References}

Andrić P, Meyer AS, Jensen PA, Dam-Johansen K (2010) Reactor design for minimizing product inhibition during enzymatic lignocellulose hydrolysis: I. Significance and mechanism of cellobiose and glucose inhibition on cellulolytic enzymes. Biotechnol Adv 28:308-324 
Barham D, Trinder P (1972) An improved color reagent for the determination of blood glucose by the oxidase system. Analyst 97:142-145

Chakar FS, Ragauskas AJ (2004) Review of current and future softwood kraft lignin process chemistry. Ind Crops Prod 20:131-141

Chaturvedi V, Verma P (2013) An overview of key pretreatment processes employed for bioconversion of lignocellulosic biomass into biofuels and value added products. 3 Biotech 3:415-431

Chen Y (2011) Development and application of co-culture for ethanol production by co-fermentation of glucose and xylose: a systematic review. J Ind Microbiol Biotechnol 38:581-597

Edwards MC, Doran-Peterson J (2012) Pectin-rich biomass as feedstock for fuel ethanol production. Appl Microbiol Biotechnol 95:565-575

Galbe M, Zacchi G (2007) Pretreatment of lignocellulosic materials for efficient bioethanol production. Adv Biochem Eng/Biotechnol 108:41-65

Hausser N, Marinkovic S, Estrine B (2013) New method for lignocellulosic biomass polysaccharides conversion in butanol, an efficient route for the production of butyl glycosides from wheat straw or poplar wood. Cellulose 20:2179-2184

Kumar R, Wyman CE (2009) Effects of cellulose and xylanase enzymes on the deconstruction of solids from pretreatment of poplar by leading technologies. Biotechnol Prog 25:302-314

Ludot C, Estrine B, Hoffmann N, Le Bras J, Marinkovic S, Muzart J (2014) Manufacture of dodecyl pentosides surfactants by wood hemicelluloses transglycosidation: a potential pretreatment process for wood biomass valorization. Ind Crops Prod 58:335-339
Miao Y, Chen JY, Jiang X, Huang Z (2012) Kinetic studies on the product inhibition of enzymatic lignocellulose hydrolysis. Appl Biochem Biotechnol 167:358-366

Miller GL (1959) Use of dinitrosalicylic acid reagent for determination of reducing sugar. Anal Chem 31:426-428

Modrzejewski K, Olszewski J, Rutkowski J (1969) Analysis in papermaking industry. Editorial office of the Lodz University of Technology, Lodz, pp 60-89, 206-250

Santi C Jr, Milagres AMF, Ferraz A, Carvalho W (2013) The effects of lignin removal and drying on the porosity and enzymatic hydrolysis of sugarcane bagasse. Cellulose 20:3165-3177

Stoutenburg RM, Perrotta JA, Nakas JP (2011) Overcoming inhibitors in a hemicellulosic hydrolysate: improving fermentability by feedstock detoxification and adaptation of Pichia stipitis. J Ind Microbiol Biotechnol 38:1939-1945

Sun R, Lawther JM, Banks WB (1996) Fractional and structural characterization of wheat straw hemicelluloses. Carbohydr Polym 29:325-331

Sun R, Lawther JM, Banks WB, Xiao B (1997) Effect of extraction procedure on the molecular weight of wheat straw lignins. Ind Crops Prod 6:97-106

Van Dyk JS, Pletschke BI (2012) A review of lignocellulose bioconversion using enzymatic hydrolysis and synergistic cooperation between enzymes - factors affecting enzymes, conversion and synergy. Biotechnol Adv 30:1458-1480

Wilson DB (2009) Cellulases and biofuels. Curr Opin Biotechnol 20:295-299

World Pulp Monthly (2014) Analysis and forecasts of the International Pulp Market, RISI, January 2014, p 9 